\title{
INTERNATIONAL JOURNAL OF SCIENTIFIC RESEARCH
}

FREQUENCY OF DIABETIC RETINOPATHY IN TYPE 2 DIABETES MELLITUS WITH REFERENCE TO RISK FACTORS IN A TERTIARY CARE HOSPITAL IN SOUTH WESTERN MAHARASHTRA

\begin{tabular}{l} 
Ophthalmology \\
Dr. Satish Desai \\
\hline Dr. Priyanka A. \\
Mahendrakar*
\end{tabular}

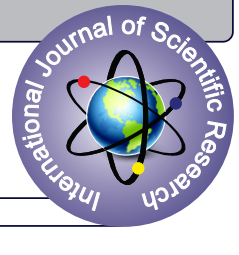

Associate Professor, Department of Ophthalmology, Government Medical College, Miraj

\author{
MS Ophthalmology*Corresponding Author
}

\section{ABSTRACT}

AIM: To estimate the frequency of Diabetic Retinopathy and the possible risk factors associated with Diabetic Retinopathy.

MATERIALS AND METHODS: All patients of diagnosed type 2 Diabetes Mellitus attending Ophthalmology Outpatient Department in Government Medical College and Hospital, Miraj during the study period were included. History was taken and a complete ophthalmic examination was done. Diabetic Retinopathy was graded according to ETDRS classification. Data was analyzed using SPSS 22 version software. RESULT: A total of 275 patients with diagnosed Diabetes Mellitus were examined. Frequency of diabetic retinopathy in the study was $30.91 \%$. Significant association was found with male gender $(\mathrm{p}=0.008)$, duration of Diabetes Mellitus more than 10 years $(\mathrm{p}<0.001)$, positive family history $(p<0.001)$, use of insulin $(p<0.001)$, raised systolic and diastolic blood pressure $(p<0.001)$, fasting and post prandial blood sugar levels $(p<0.001)$. Age, smoking status and body mass index were not found to be significant risk factors for the development of diabetic retinopathy.

\section{KEYWORDS}

Diabetic retinopathy, Diabetes Mellitus

\section{INTRODUCTION}

Diabetes Mellitus currently affects 425 million people worldwide. It is anticipated that the number of people with diabetes will be more than double as a consequence of population aging, increased life expectancy, obesity, reduced physical fitness, urbanization and improved detection ${ }^{1}$

Diabetic Retinopathy is the most common microvascular complication of diabetes and was until recently regarded as the most prevalent cause of visual impairment in the working age population in developed countries ${ }^{2}$.

Patients with Diabetic retinopathy are 25 times more likely to become blind than non diabetics

In the Indian subcontinent, only limited data is available on the prevalence of Diabetic Retinopathy in the general population. Studies of various complications in Indian diabetics is therefore of great interest. Hence, this study was undertaken to screen the population with Type 2 Diabetes Mellitus for diabetic retinopathy and to explore risk factors for developing diabetic retinopathy among them.

\section{OBJECTIVES}

- To study the frequency of Diabetic Retinopathy among diagnosed Type 2 Diabetes Mellitus patients.

- To study the relation of Diabetic Retinopathy with risk factors such as age, gender, duration of diabetes, blood sugar levels, ongoing pharmacotherapy, family history.

\section{MATERIALSAND METHODS}

After receiving approval from our local ethics committee and prior written informed consent a descriptive hospital based cross sectional study was done on patients with diagnosed type 2 Diabetes Mellitus attending the Ophthalmology Outpatient Department at Government Medical College and Hospital, Miraj considering the inclusion and exclusion criteria over a period of 18 months (January 2017 to June 2018).

A detailed history, ocular examination and relevant systemic examination was done.

History included the following general information of the patient, duration since diagnosis of type 2 Diabetes Mellitus, treatment modality for diabetes, family history, smoking habit and ocular history. A detailed ophthalmological examination included recording of visual acuity (best corrected visual acuity), examination of ocular adnexa and extraocular structures, Slit lamp biomicroscopic examination of the anterior segment. Pupils were dilated using mydriatic agents namely combination of $0.8 \%$ Tropicamide and 5\% Phenylephrine eye drop 3 times at an interval of 10 minutes. Detailed examination of the posterior pole was done using direct ophthalmoscope and slit lamp biomicroscope with +90D lens. Retinal periphery was examined by indirect ophthalmoscopy using $+20 \mathrm{D}$ lens. Diabetic retinopathy was classified according to Modified Airlie House classification - Early Treatment Diabetic Retinopathy Study (ETDRS). The worse affected eye of the participant was considered for the purpose of further statistical analysis

A thorough systemic examination was done with measurement of height, weight and body mass index, systolic and diastolic blood pressure in supine position, fasting plasma glucose and 2 hour post prandial plasma glucose.

Data was analysed using SPSS 22 version software. Categorical data was represented in the form of frequencies and proportions. Chisquare test was used as test of significance for qualitative data. Continuous data was represented as mean and standard deviation.

Independent $t$ test was used as test of significance to identify the mean difference between two quantitative variables.

$\mathrm{p}$ value (Probability that the result is true) of $<0.05$ was considered as statistically significant after assuming all the rules of statistical tests.

\section{INCLUSION CRITERIA:}

All patients of diagnosed type 2 Diabetes Mellitus attending Ophthalmology Outpatient Department during the study period who are willing to participate in the study.

\section{EXCLUSION CRITERIA}

- Patients who are non-compliant

- Pregnant and lactating women.

- Immunocompromised patients.

- Patients with other systemic diseases.

\section{RESULTS}

A total of 275 diagnosed patients of type 2 Diabetes Mellitus attending the Ophthalmology Outpatient Department were included in the study. $4.7 \%$ were in the age group $<50$ years, $26.2 \%$ were in the age group 51 to 60 years, $51.6 \%$ were in the age group 61 to 70 years and $17.5 \%$ were in the age group 71 to 80 years. Mean age of the study population was $64.55+8.236$ years. $56.4 \%$ were males and $43.6 \%$ were females. Duration of Diabetes Mellitus was $<5$ years in $49.8 \%, 6$ to 10 years in $30.2 \%$ and $>10$ years in $20 \%$. In the study $17.5 \%$ had family history of Diabetes Mellitus and $11.6 \%$ were smokers. Treatment protocol in $13.5 \%$ was dietary and lifestyle modifications, in $66.5 \%$ was Oral Hypoglycemic agents and in $20 \%$ was Insulin. $88.4 \%$ were Nonsmokers and $11.6 \%$ were smokers.

In the study out of 275 subjects, $30.9 \%$ had diabetic retinopathy and in $69.1 \%$ diabetic retinopathy was absent. $82.35 \%$ had Non Proliferative 
Diabetic Retinopathy (NPDR) and $17.65 \%$ had Proliferative Diabetic Retinopathy (PDR). Among NPDR patients $23.52 \%$ had Mild NPDR, $37.65 \%$ had Moderate NPDR, $16.47 \%$ had Severe NPDR and $4.71 \%$ had Very Severe NPDR.

$20 \%$ of the patients with diabetic retinopathy had Clinically Significant Macular Edema (CSME). Overall among diabetic patients, CSME was present in $6.18 \%$

Gender, duration of diabetes mellitus, family history and treatment modality were significant risk factors for diabetic retinopathy. Age and smoking status did not affect the presence of diabetic retinopathy significantly. Diabetic retinopathy was commonly seen among males $(37.4 \%)$, those with longer duration of DM i.e. $>10$ years $(70.9 \%)$, those with positive family history $(70.8 \%)$, those who were on Insulin $(61.8 \%)$ and among smokers $(43.8 \%)$. [Table-1]

Table 1: Association between probable risk factors and Diabetic Retinopathy

\begin{tabular}{|c|c|c|c|c|c|c|}
\hline \multirow{2}{*}{\multicolumn{2}{|c|}{ Parameter }} & \multicolumn{2}{|c|}{\begin{tabular}{|l|} 
Diabetic \\
Retinopathy \\
present
\end{tabular}} & \multicolumn{2}{|c|}{\begin{tabular}{|l|} 
Diabetic \\
Retinopathy \\
absent
\end{tabular}} & \multirow[t]{2}{*}{ P value } \\
\hline & & \begin{tabular}{|l|} 
No. of \\
subjects
\end{tabular} & \begin{tabular}{|l} 
Percenta \\
ge
\end{tabular} & $\begin{array}{l}\text { No. of } \\
\text { subjects }\end{array}$ & \begin{tabular}{|l|} 
Percenta \\
ge
\end{tabular} & \\
\hline \multirow[t]{4}{*}{ Age } & $<50$ years & 3 & $23.1 \%$ & 10 & $76.9 \%$ & \multirow[t]{4}{*}{0.811} \\
\hline & \begin{tabular}{|l|}
51 to 60 \\
years
\end{tabular} & 25 & $34.7 \%$ & 47 & $65.3 \%$ & \\
\hline & \begin{tabular}{|l|}
61 to 70 \\
years
\end{tabular} & 43 & $30.3 \%$ & 99 & $69.7 \%$ & \\
\hline & $>70$ years & 14 & $29.2 \%$ & 34 & $70.8 \%$ & \\
\hline \multirow[t]{2}{*}{ Gender } & Female & 27 & $22.5 \%$ & 93 & $77.5 \%$ & \multirow[t]{2}{*}{$0.008^{*}$} \\
\hline & Male & 58 & $37.4 \%$ & 97 & $62.6 \%$ & \\
\hline \multirow{3}{*}{$\begin{array}{l}\text { Duration } \\
\text { of } \\
\text { Diabetes }\end{array}$} & $<5$ years & 21 & $15.3 \%$ & 116 & $84.7 \%$ & \multirow{3}{*}{$\begin{array}{l}<0.001 \\
*\end{array}$} \\
\hline & $\begin{array}{l}6 \text { to } 10 \\
\text { years }\end{array}$ & 25 & $30.1 \%$ & 58 & $69.9 \%$ & \\
\hline & $>10$ years & 39 & $70.9 \%$ & 16 & $29.1 \%$ & \\
\hline \multirow{2}{*}{\begin{tabular}{|l|} 
Family \\
History
\end{tabular}} & No & 51 & $22.5 \%$ & 176 & $77.5 \%$ & \multirow{2}{*}{$\begin{array}{l}<<0.001 \\
*\end{array}$} \\
\hline & Yes & 34 & $70.8 \%$ & 14 & $29.2 \%$ & \\
\hline \multirow{3}{*}{\begin{tabular}{|l|} 
Treatme \\
nt \\
Modality
\end{tabular}} & Diet & 3 & $8.1 \%$ & 34 & $91.9 \%$ & \multirow{3}{*}{$\begin{array}{l}<0.001 \\
*\end{array}$} \\
\hline & OHA & 48 & $26.2 \%$ & 135 & $73.8 \%$ & \\
\hline & $y$ Insulin & 34 & $61.8 \%$ & 21 & $38.2 \%$ & \\
\hline \multirow[t]{2}{*}{ Smoking } & No & 71 & $29.2 \%$ & 172 & $70.8 \%$ & \multirow[t]{2}{*}{0.094} \\
\hline & Yes & 14 & $43.8 \%$ & 18 & $56.2 \%$ & \\
\hline
\end{tabular}

There was significant difference in duration of diabetes, systolic blood pressure, diastolic blood pressure, fasting blood sugar and post prandial blood sugar between the patients with diabetic retinopathy and those without diabetic retinopathy. [Table-2].

Table 2: Association between quantitative variables and Diabetic Retinopathy

\begin{tabular}{|c|c|c|c|c|c|}
\hline \multirow{2}{*}{ Parameter } & \multicolumn{2}{|c|}{$\begin{array}{c}\text { Diabetic } \\
\text { Retinopathy } \\
\text { present }\end{array}$} & \multicolumn{2}{|c|}{$\begin{array}{c}\text { Diabetic } \\
\text { Retinopathy } \\
\text { absent }\end{array}$} & \multirow{2}{*}{ P value } \\
\cline { 2 - 5 } & Mean & SD & Mean & SD & \\
\hline $\begin{array}{c}\text { Duration of } \\
\text { Diabetes }\end{array}$ & 11.13 & 6.31 & 5.23 & 3.68 & $<0.001^{*}$ \\
\hline Systolic BP & 130.52 & 14.44 & 123.52 & 12.03 & $<0.001^{*}$ \\
\hline Diastolic BP & 83.95 & 8.52 & 77.62 & 8.66 & $<0.001^{*}$ \\
\hline Body Mass Index & 23.24 & 1.71 & 22.89 & 1.54 & 0.094 \\
\hline Fasting BSL & 141.66 & 47.68 & 91.33 & 33.32 & $<0.001^{*}$ \\
\hline Post Prandial BSL & 232.42 & 89.03 & 181.54 & 48.32 & $<0.001^{*}$ \\
\hline
\end{tabular}

\section{DISCUSSION}

Diabetic Retinopathy is an emerging health problem with involvement of both medical and economic considerations. It is now considered as the commonest cause of new cases of legal blindness among the working age individuals in developing and developed countries.

In the present study, different types of diabetic retinopathy were observed in 85 patients out of the total 275 patients i.e. the frequency of Diabetic Retinopathy in our study was $30.91 \%$.

The results of this study were comparable with other studies. [Table-3, Table-4]
Table 3: Evidence base for Prevalence of Diabetic Retinopathy in India

\begin{tabular}{|c|c|c|c|c|}
\hline Study and Authors & Year & $\begin{array}{c}\text { Region } \\
\text { Type of DM }\end{array}$ & $\begin{array}{c}\text { Total no. } \\
\text { of cases }\end{array}$ & $\begin{array}{c}\text { \% of } \\
\text { DR }\end{array}$ \\
\hline Gadkari SS et al $^{3}$ & 2016 & $\begin{array}{c}\text { Urban and rural, India } \\
\text { Type 1 and 2 DM }\end{array}$ & 5130 & $21.7 \%$ \\
\hline $\begin{array}{c}\text { Raman R et al } \\
\text { SN-DREAMS III }\end{array}$ & 2014 & $\begin{array}{c}\text { Rural, South India } \\
\text { Type 2 DM }\end{array}$ & 13079 & $10.3 \%$ \\
\hline $\begin{array}{c}\text { Namperumalsamy P P } \\
\text { et al }^{5}\end{array}$ & 2009 & $\begin{array}{c}\text { Urban and rural } \\
\text { Tamil Nadu, India } \\
\text { Type 2 DM }\end{array}$ & 25969 & $10.8 \%$ \\
\hline $\begin{array}{c}\text { Raman R et al } \\
\text { SN-DREAMS II }\end{array}$ & 2008 & $\begin{array}{c}\text { Urban, South India } \\
\text { (Chennai) Type 2 DM }\end{array}$ & 5999 & $18.0 \%$ \\
\hline $\begin{array}{c}\text { Rema M et al, } \\
\text { CURES }\end{array}$ & 2005 & $\begin{array}{c}\text { Urban, South India } \\
\text { (Chennai) Type 2 DM }\end{array}$ & 1736 & $17.6 \%$ \\
\hline $\begin{array}{c}\text { Agrawal RP et al } \\
8\end{array}$ & 2000 & $\begin{array}{c}\text { Urban and rural , } \\
\text { Bikaner, India Type 2 } \\
\text { DM }\end{array}$ & 4400 & $28.9 \%$ \\
\hline Dandona L et al & 1999 & $\begin{array}{c}\text { Urban population } \\
\text { Hyderabad Type 2 } \\
\text { DM }\end{array}$ & 2532 & $22.4 \%$ \\
\hline Rema M et al ${ }^{10}$ & 1996 & $\begin{array}{c}\text { Urban and rural, } \\
\text { South India Type 2 } \\
\text { DM }\end{array}$ & 6792 & $34.1 \%$ \\
\hline
\end{tabular}

Table 4: Evidence base for Prevalence of Diabetic Retinopathy in different populations throughout the world

\begin{tabular}{|c|c|c|c|c|}
\hline Study and Authors & Year & Region & $\begin{array}{c}\text { Total } \\
\text { no. of } \\
\text { cases }\end{array}$ & $\begin{array}{c}\text { \%o of } \\
\text { DR }\end{array}$ \\
\hline $\begin{array}{c}\text { Jin G et al, The Yangxi } \\
\text { Eye Study }\end{array}$ & 2017 & $\begin{array}{c}\text { Rural China } \\
\text { Type 2 DM }\end{array}$ & 476 & $8.19 \%$ \\
\hline $\begin{array}{c}\text { Wong T et al, } \\
\text { The Singapore Malay } \\
\text { Eye Study }\end{array}$ & 2008 & $\begin{array}{c}\text { Singapore } \\
\text { Type 2 DM }\end{array}$ & 757 & $35.0 \%$ \\
\hline $\begin{array}{c}\text { Varma R et al } \\
\text { Los Angeles Latino Eye } \\
\text { Study }\end{array}$ & 2004 & $\begin{array}{c}\text { Los Angeles, } \\
\text { USA } \\
\text { Type 2 DM }\end{array}$ & 1217 & $46.9 \%$ \\
\hline $\begin{array}{c}\text { Leske MC et al, } \\
\text { Barbados Eye Studies }\end{array}$ & 2003 & $\begin{array}{c}\text { Barbados, West } \\
\text { Indies } \\
\text { Type 2 DM }\end{array}$ & 306 & $28.8 \%$ \\
\hline $\begin{array}{c}\text { Mitchell P et al, } \\
\text { The Blue Mountains Eye } \\
\text { Study }\end{array}$ & 1998 & $\begin{array}{c}\text { Urban area west } \\
\text { of Sydney } \\
\text { Type 2 DM }\end{array}$ & 252 & $29.0 \%$ \\
\hline $\begin{array}{c}\text { Klein R et al, Beaver } \\
\text { Dam Eye Study }\end{array}$ & $1988-90$ & $\begin{array}{c}\text { Beaver Dam, } \\
\text { Wisconsin, USA } \\
\text { Type 2 DM }\end{array}$ & 410 & $35.1 \%$ \\
\hline $\begin{array}{c}\text { Klein R et al, WESDR } \\
\text { 17,18 }\end{array}$ & $1980-82$ & $\begin{array}{c}\text { Southern } \\
\text { Wisconsin, USA } \\
\text { Type 1 and 2 DM }\end{array}$ & 1313 & $50.3 \%$ \\
\hline
\end{tabular}

In the present study of the total 85 patients with diabetic retinopathy, 70 patients $(82.35 \%)$ had non proliferative diabetic retinopathy (NPDR), 15 patients $(17.65 \%)$ had proliferative diabetic retinopathy (PDR). Mild NPDR was present in 20 patients $(23.52 \%)$, Moderate NPDR was present in $32(37.65 \%)$, Severe NPDR was present in $14(16.47 \%)$ and Very Severe NPDR was present in $4(4.71 \%)$ among the patients with diabetic retinopathy. More number of cases of NPDR compared to PDR were also observed by Rema M et al $(1996)^{10}$, Dandona L et $\mathrm{al}^{9}$, Agrawal RP et al ${ }^{8}$, Narendran $V$ et al $^{19}$, Rema M et al (CURES)

Clinically significant macular edema (CSME) was seen in 17 patients $(20 \%)$ among the patients with diabetic retinopathy and in $6.18 \%$ patients among all the study subjects which was similar to the findings of Varma et al (LALES) ${ }^{13}(6.2 \%)$, Broadbent DM et al (Liverpool Eye Disease Study $)^{20}(6.4 \%)$, Leske MC et al (Barbados Eye Study $)^{14}(4.5 \%)$.

In the present study, diabetic retinopathy was seen in $23.1 \%$ patients $<50$ years, $34.7 \%$ between $51-60$ years, $30.3 \%$ between $61-70$ years and $29.2 \%$ in those $>70$ years. The association was not found to be significant $(\mathrm{P}=0.811)$. It did show an increased prevalence in sixth decade compared with the fifth decade of life, in the seventh decade, it levelled off and later it dropped. Similar trends also were observed by Raman R et al (SN-DREAMS II) ${ }^{6}$, Agrawal RP et $\mathrm{al}^{8}$, The Beaver Dam Study ${ }^{16}$, The Blue Mountain Eye Study ${ }^{15}$ and The Wisconsin Epidemiologic Study of Diabetic Retinopathy (WESDR) ${ }^{18}$. 
$37.4 \%$ males and $22.5 \%$ females had diabetic retinopathy. This difference was found to be statistically significant $(\mathrm{P}=0.008)$. A similar male preponderance in the presence of diabetic retinopathy was found by Rema $\mathrm{M}$ et al (CURES) ${ }^{7}$, Raman R et al (SN-DREAMS II) ${ }^{6}$, Namperumalasamy P et $\mathrm{al}^{5}$, UKPDS study ${ }^{21}$ and Dandona et al ${ }^{9}$.

The mean duration since diagnosis in our study in patients with diabetic retinopathy was $11.3 \pm 6.31$ years and in those without retinopathy was $5.23+3.68$ years.

Increase in duration of diabetes mellitus was a strong predictor for the development of diabetic retinopathy in the present study $(\mathrm{P}<0.001)$ and was also reported by Varma R et $\mathrm{al}^{13}$, Wong $\mathrm{T}$ et $\mathrm{al}^{12}$ and Jin $\mathrm{G}$ et $\mathrm{al}^{11}$. Rema M et al in CURES (2005) $)^{7}$ stated that $41.8 \%$ patients had diabetic retinopathy after 15 years of diabetes. In addition they have also stated that for every 5 year increase in duration of diabetes, the risk of developing increases by 1.89 times $^{7}$.

Positive family history was found to be a significant risk factor in the present study and similar results were reported by Rema $\mathrm{M}$ et al (CURES) ${ }^{7}$

The present study, diabetic retinopathy was present in $61.8 \%$ of the patients on insulin as a treatment modality compared to $26.2 \%$ in those on oral hypoglycemic agents and $8.1 \%$ in the ones on dietary and lifestyle modifications. This association was found to be statistically significant $(\mathrm{P}<0.001)$. This was probably because of longer duration of diabetes or poor glycemic control prompting the use of insulin. These results are consistent with various other studies like Klien et al $(\text { WESDR })^{17,18}$, Broadbent DM et al ${ }^{20}$, Agrawal RP et al ${ }^{8}$, Leske MC et al (Barbados Eye Study) $)^{14}$, Raman R et al (SN-DREAMS II and SNDREAMS III) ${ }^{6,4}$, Gadkari SS et al ${ }^{3}$.

Increased systolic and diastolic blood pressure was found to have significant association with presence of diabetic retinopathy in the present study similar to the findings of Raman R et al (SN-DREAMS III) ${ }^{4}$, Raman R et al (SN-DREAMS III) ${ }^{4,6}$ and UKPDS $^{21}$.

Both fasting and post prandial blood sugar levels were significantly high in patients with diabetic retinopathy $(\mathrm{P}<0.001)$ in our study. Most of the studies considered glycosylated haemoglobin for the association of glycemic status with presence of diabetic retinopathy instead of blood sugar levels. Rema M et al (CURES) ${ }^{7}$, Agrawal RP et al ${ }^{8}$ and Raman $\mathrm{R}$ et al (SN-DREAMS II) ${ }^{6}$ supported the evidence that poor glycemic control is an important risk factor for development and progression of diabetic retinopathy.

Body mass index and smoking status were not found to have statistically significant association with diabetic retinopathy in the present study. Raman R et al (SN-DREAMS II) ${ }^{6}$ also reported that prevalence of diabetic retinopathy in patients who were smokers was more than non-smokers but the association was not statistically significant. Studies conducted by Narendran $\mathrm{V}$ et $\mathrm{al}^{19}$, Jin $\mathrm{G}$ et $\mathrm{al}^{11}$ and Mitchell $\mathrm{P}$ et a ${ }^{15}$ also found no association between BMI and presence of diabetic retinopathy.

\section{CONCLUSION}

Diabetic Retinopathy can be considered to be a major health problem in patients with Type 2 Diabetes Mellitus. Clinically Significant Macular Edema which is a major cause of reduced visual acuity in patients with Diabetic Retinopathy and should be detected early in the course of the disease. As the duration of Diabetes Mellitus increases, the chances of developing Diabetic Retinopathy also increase and thus the screening intervals should be reduced with increased duration. Also the higher frequency of retinopathy in the patients requiring insulin is probably due to prolonged exposure to hyperglycemia and possible delay in the initiation of insulin treatment. Thus, targeting these patients during screening is essential. And lastly strict control of blood pressure and blood sugar levels can possibly delay the development and progression of Diabetic Retinopathy.

\section{Financial Support: nil}

Conflicts of interest: nil

\section{REFERENCES}

1. International iabetes Federation. Diabetes Atlas. 8th ed. 2017.

2. Heng LZ, Comyn O, Peto T, Tadros C, Ng E, Sivaprasad S, Hykin PG. Diabetic retinopathy: pathogenesis, clinical grading, management and future developments. Diabet Med. 2013 Jun;30(6):640-50.
3. National society to prevent blindness. In: Visual problems in the US data analysis definition, data sources, detailed data tables, analysis, interpretation. New York: National society to prevent blindness 1980:1-46.

4. Gadkari SS, Maskati QB, Nayak BK. Prevalence of diabetic retinopathy in India: The All India Ophthalmological Society Diabetic Retinopathy Eye Screening Study 2014. Indian J Ophthalmol 2016;64:38-44

5. Raman R, Ganesan S, Pal SS, et al. Prevalence and risk factors for diabetic retinopathy in rural India. Sankara Nethralaya Diabetic Retinopathy Epidemiology and Molecula Genetic Study III (SN-DREAMS III), report no 2. BMJ Open Diabetes Research and Care 2014;2:000005. doi:10.1136/bmjdrc-2013-000005

6. Namperumalsamy P, Kim R, Vignesh TP, Nithya N, Royes J, Gijo T, et al. Prevalence and risk factors for diabetic retinopathy: a population-based assessment from Theni District, south India. Postgrad Med J. 2009 Dec;85(1010):643-8.

7. Raman R, Rani PK, Reddi Rachepalle S, Gnanamoorthy P, Uthra S, Kumaramanickave $\mathrm{G}$, et al. Prevalence of Diabetic Retinopathy in India. Sankara Nethralaya Diabetic Retinopathy Epidemiology and Molecular Genetics Study Report 2. Ophthalmology [Internet]. 2009;116(2):311-8

8. Rema M, Premkumar S, Anitha B, et al. Prevalence of diabetic retinopathy in Urban India: the Chennai urban rural epidemiology study (CURES) eye study, I. Invest Ophthalmol Vis Sci. 2005;46:2328-2333.

9. Agrawal RP, Ranka M, Beniwal R, Gothwal SR, Jain GC, Kochar DK et al. Prevalence of diabetic retinopathy in type 2 diabetes in relation to risk factors: Hospital based study. Int J Diab Dev Countries. 2003:23:16-19.

10. Dandona L, Dandona R, Naduvilath TJ, et al Population based assessment of diabetic retinopathy in an urban population in southern India British Journal of Ophthalmology 1999;83:937-940

11. Rema M., Ponnaiya M., Mohan V. Prevalence of retinopathy in non insulin dependen diabetes mellitus at a diabetes centre in Southern India. Diab Res Clin Pract 1996; 34 29-36.

12. Jin G, Xiao W, Ding X, et al. Prevalence of and risk factors for diabetic retinopathy in rural Chinese population: the Yangxi Eye Study. Invest Ophthalmol Vis Sci. 2018;59:5067-5073. https://doi.org/10.1167/iovs.18-24280.

13. Tien Y Wong, Ning Cheung, Wan Ting Tay, Jie Jin Wang, Tin Aung, Seang Mei Saw et al. Prevalence and Risk Factors for Diabetic Retinopathy: The Singapore Malay Eye Study. Ophthalmology. November 2008; 115(11):1869-75.

14. Varma R, Torres M, Pena F, Klein R, Azen S. Prevalence of diabetic retinopathy in adul Latinos: The Los Angeles Latino Eye Study. Ophthalmology. July 2004;111(7): 1298- 1306.

15. Leske MC, Wu SY, Hennis A, Nemesure B, Hyman L, Schachat A; Barbados Eye Studies Group. Incidence of diabetic retinopathy in the Barbados Eye Studies. Ophthalmology. 2003 May;110(5):941-7.

16. Mitchell P, Smith W, Wang JJ, Attebo K. Prevalence of diabetic retinopathy in an older community. The Blue Mountains Eye Study. Ophthalmology. 1998 Mar;105(3):406-11.

17. Klein R, Kl in BE, Moss SE, Linton KL. The Beaver Dam Eye Study. Retinopathy in E Lin adults with newly Ophthalmology.1992 Jan:99(1):58-62.e

18. Klein R, Klein BEK, Moss SE, et al. The Wisconsin epidemiologic study of diabetic retinopathy. II. Prevalence and risk of diabetic retinopathy when age at diagnosis is less than 30 years. Arch Ophthalmol. 1984;102:520-526.

19. Klein R, Klein BEK, Moss SE, et al. The Wisconsin epidemiologic study of diabetic retinopathy. III. Prevalence and risk of retinopathy when age at diagnosis is 30 or more years. Arch Ophthalmol. 1984;102:527-532.

20. Narendran V, John RK, Raghuram A, Ravindran RD, Nirmalan PK, Thulasiraj RD. Diabetic retinopathy among self reported diabetics in southern India: a population based assessment 2002:(4):1014-8.

21. Broadbent DM, Scott JA, Vora JP, Harding SP. Prevalence of diabetic eye disease in an inner city population : the Liverpool Diabetic Eye Study. 1999;160-5.

22. UK Prospective diabetes study (UKPDS) group. Intensive blood glucose control with sulphonylureas or insulin compared with conventional treatment and risk of complications in patients with type-2 diabetes (UKPDS 33). Lancet 1998;352:837-53. 